\title{
PERANAN POLRI DALAM PERLINDUNGAN TERHADAP SAKSI DAN KORBAN PADA PROSES PERKARA PIDANA
}

\author{
Suyoto \\ Universitas Muria Kudus \\ suyoto@umk.ac.id
}

\begin{abstract}
ABSTRAK
Lahirnya Undang-Undang Perlindungan Saksi dan Korban dianggap sangat penting dalam rangka perlindungan saksi dan korban terhadap hakhak individunya. Kedudukan saksi dalam proses perkara pidana menempati posisi kunci. Posisi penting yang dimiliki oleh saksi dalam proses perkara pidana, maka sudah menjadi kewajiban bagi aparat penegak hukum, khususnya aparat kepolisian untuk memberikan perlindungan saksi dan korban. Perlindungan saksi tersebut merupakan bagian dari tugas pokok lembaga kepolisian dalam rangka memelihara keamanan dan ketertiban (peace and order maintenance) dan penegakan hukum (law enforcement).

Undang-undang perlindungan saksi dan korban merupakan karya terbaru bangsa dalam perkembagan hukum pidana Indonesia yang mengilhami sebuah cita-cita hukum yang melindungi hak asasi segenap bangsa Indonesia terutama hak saksi dan korban dalam proses peradilan pidana. Menilik pentingnya saksi sebagaimana ditegaskan dalam ketentuan Pasal 184 Pasal 185 KUHAP, maka sudah sewajarnya saksi atau korban dalam upaya penegakan hukum diberikan perlindungan, sehingga dalam memberikan kesaksiannya di depan pengadilan, saksi merasa aman dan bebas dari ancaman / tekanan baik fisik atau psikis terhadap diri dan keluarganya.

Sasaran perlindungan yang diberikan Undang-Undang No.13 Tahun 2006, terhadap saksi dan korban diatur dalam Pasal 5 bahwa hak yang diberikan kepada saksi dan/atau korban tindak pidana dalam kasus-kasus tertentu sesuai dengan keputusan Lembaga Perlindungan Saksi dan Korban. Pasal 36 ayat (1) Undang-Undang No.13 Tahun 2006, memberikan mandat kepada Lembaga Perlindungan Saksi dan Korban untuk bekerjasama dengan instansi berwenang lainnya yang terkait. Perlindungan hukum terhadap saksi oleh pihak POLRI dilakukan berdasarkan tugasnya yang diatur dalam ketentuan Pasal 2, Pasal 13 sampai dengan Pasal 15 Undang-Undang Nomor 2 Tahun 2002 tentang Kepolisian Negara Republik Indonesia. Perlindungan hukum diberikan agar saksi dan korban dapat memberikan kesaksian dengan sebaik-baiknya.
\end{abstract}

Kata kunci: Perlindungan saksi, proses peradilan pidana. 


\section{PENDAHULUAN}

Keberadaan saksi merupakan suatu elemen yang sangat menentukan dalam keberhasilan mengungkap suatu kasus dalam proses peradilan pidana, dengan kata lain dalam proses peradilan pidana bahwa saksi merupakan kunci untuk memperoleh kebenaran materiel yang merupakan bahan bagi hakim dalam menentukan suatu putusan. Hal tersebut sangat beralasan karena saksi merupakan alat bukti pertama dalam acara pmeriksaan biasa, baru kemudian diikuti dengan alat bukti lainnya yaitu keterangan ahli, surat, petunjuk dan keterangan terdakwa sebagaimana diatur dalam Pasal 184 ayat (1) Kitab Undang-Undang Hukum Acara Pidana yang selanjutnya disingkat KUHAP. Oleh karena itu kedudukan saksi dalam proses perkara pidana menempati posisi kunci. Sebagai alat bukti utama, tentu dampaknya sangat terasa bila dalam suatu perkara tidak diperoleh saksi. Dengan demikian pentingnya kedudukan saksi dalam proses peradilan pidana, telah dimulai sejak awal proses peradilan pidana. Begitu juga dalam proses selanjutnya, keterangan saksi sebagai alat bukti utama menjadi acuan hakim dalam memutus besalah atau tidaknya terdakwa. Dengan demikian jelas bahwa saksi mempunyai kontribusi yang sangat besar dalam upaya menegakkan hukum dan keadilan.

Keterangan saksi adalah salah satu alat bukti dalam perkara pidana yang berupa keterangan dari saksi mengenai suatu peristiwa pidana yang ia dengar sendiri, ia lihat sendiri, dan ia alami sendiri dengan menyebut alasan dari pengetahuannya itu (Pasal 1 butir (27) KUHAP). Saksi adalah orang yang dapat memberikan keterangan guna kepentingan penyidikan, penuntutan dan peradilan tentang suatu perkara pidana yang ia dengar sendiri, ia lihat sendiri, dan ia alami sendiri (Pasal 1 butir (26) KUHAP). ${ }^{1}$ Maka tidaklah mustahil saksi adalah juga korban (pihak yang dirugikan dari peristiwa tersebut). Saksi diharapkan dapat menjelaskan rangkaian kejadian yang berkaitan dengan sebuah peristiwa yang menjadi obyek pemeriksaan di muka persidangan.

\footnotetext{
${ }^{1}$ Muhammad Taufik Makarao, Hukum Acara Pidana Dalam Teori dan Praktek, Jakarta, Ghalia Indonesia, 2002, hlm. 107
} 
Saksi, bersama alat bukti lainnya akan membantu hakim untuk menjatuhkan putusan yang adil dan obyektif berdasarkan fakkta-fakta hukum yang diungkapkan di depan persidangan. Berkaitan dengan itu, saksi merupakan salah satu faktor penting dalam pembuktian atau pengungkapan fakta yang akan dijadikan acuaan dalam menemukan bukti-bukti lain untuk menguatkan sebuah penyelidikan, penyidikan, dan bahkan pembuktian di pengadilan. Pentingnya peran saksi dalam proses penegakan hukum terutama hukum pidana tentunya membawa konsekuensi tersendiri bagi orang yang dijadikan saksi, baik itu saksi korban dan sksi pelapor maupun saksi-saksi lain dalam pembuktian pelaku tindak pidana.

Perlindungan saksi sangat dibutuhkan dalam menangani kejahatan berat, seperti terorisme, pelanggaran HAM, korupsi, dan money laundering. Perlindungan saksi memang tidak hanya ditujukan bagi pelapor, tetapi juga bagi korban tindak pidana. Seringkali saksi penting dalam tindak pidana berat menjadi sasaran ancaman, teror dan intimidasi. Padahal, teror, intimidasi dan ancaman itu dapat dikategorikan sebagai abstraction of justice atau gangguan terhadap proses peradilan. Berdasarkan pada uraian mengenai posisi penting yang dimiliki oleh saksi dalam proses perkara pidana, maka sudah menjadi kewajiban bagi aparat penegak hukum, khususnya parat kepolisian untuk memberikan perlindungan saksi dan korban. Perlindungan saksi tersebut merupakan bagian dari tugas pokok lembaga keolisian dalam rangka memelihara keamanan dan ketertiban (peace and order maintenance) dan penegakan hukum (law enforcement). ${ }^{2}$ Artinya saksi ditempatkan menjadi bagian yang tidak terpisahkan dalam rangka penyelidikan dan penyidikan guna memperlancar tugas yang diemban oleh polisi. Dengan demikian, maka jelas bahwa ketersediaan mekanisme perlindungan saksi dan korban amat penting untuk menjamin diperolehnya kebenaran materiil sekkaligus untuk memenuhi rasa keadilan bagi semua, termasuk bagi saksi dan korban yang terkait.

\footnotetext{
${ }^{2}$ Farouk Muhammad, Menuju Reformasi POLRI, cetakan I, Jakarta: PTIK Press bekerjasama dengan CV Restu Agung, 2003, hal.107
} 
Muladi menyatakan bahwa perlunya pengaturan dan perlindungan hukum bagi saksi dan korban dapat dibenarkan secara sosiologis bahwa dalam kehidupan bermasyarakat semua warga negara harus berpartisipasi penuh, sebab masyarakat dipandang sebagai sistem kepercayaan yang melembaga "system of in instuitutionalizet trust".3 Tanpa kepercayaan ini, kehidupan sosial tidak mungkin berjalan baik, sebab tidak ada pedoman atau patokan yang pasti dalam bertingkah laku. Kepercayaan ini terpadu melalui norma-norma yng diekspresikan di dalam struktur kelembagaan seperti kepolisian, kejaksan, pengadilan dan sebaginya. Maka dari itu, perlindungan terhadap saksi dan korban harus diberikan bila menginginkan proses hukum berjalan benar dan keadilan ditegakkan.

\section{Peranan dan Kedudukan Saksi Dalam}

\section{Proses Perkara Pidana}

Pada umumnya, alat bukti keterangan saksi merupakan alat bukti yang paling utama dalam

\footnotetext{
${ }^{3}$ Muladi, Hak Asasi Manusia, Politik dan Sistem Peradilan Pidana, Semarang, Badan Penerbit Universitas Diponegoro, 2002, hal.175
}

perkara pidana. Bahkan tidak ada perkara pidana yang luput dari pembuktian alat bukti keterangan saksi, dan hampir semua pembuktian perkara pidana selalu bersandar kepada pemeriksaan keterangan saksi. Sekurangkurangnya di samping pembuktian dengan alat bukti yang lain, masih selalu diperlukan pembuktian dengan alat bukti keterangan saksi.

Ditinjau dari segi nilai kekuatan pembuktian (the degree of evidence) keterangan saksi atau kesaksian agar mempunyai nilai serta kekuatan pembuktian, perlu diperhatikan beberapa pokok ketentuan yang harus dipenuhi oleh seseoorang saksi. Artinya, agar keterangan seorang saksi dapat dianggap sah sebagai alat bukti yang memiliki kekuatan pembuktian haruslah memenuhi ketentuan seperti harus mengucapkan sumpah atau janji (Pasal 160 ayat (3) KUHAP, keterangan saksi haruslah bernilai sebagai bukti (Pasal 1 angka 27 KUHAP), keterangan saksi harus diberikan di dean sidang pengadilan (Pasal 185 ayat (1) KUHAP), keterangan seorang saksi saja dianggap tidak cukup (Pasal 185 
ayat (2) KUHAP) ${ }^{4}$, dan keterangan beberapa saksi haruslah berhubungan (Pasal 185 ayat (4) KUHAP).

Sebagai catatan penting bahwa nilai kekuatan pembuktian saksi seperti yang diungkapan tersebut tidak bisa dilepaskan dengan asas atau prinsip minimum pembuktian yang dianggap cukup menurut sistem pembuktian yang diatur dalam Pasal 183 KUHAP :

a. Sekurang-kurangnya dengan 2 (dua) alat bukti yang sah, atau paling minimum kesalahan terdakwa harus dibuktikan dengan dua alat bukti yang sah;

b. Dengan demikian tidak dibenarkan dan dianggap tidak cukup membuktikan kesalahan terdakwa, jika hanya dengan satu alat bukti

\footnotetext{
4 Keterangan seorang saksi saja tidak cukup untuk membukikan bahwa terdakwa bersalah terhadap perbuatan yang didakwakan kepadanya. Asas ini lazim disingkat dengan istilah; satu saksi tidak merupakan saksi (unus testis nullus testis). Ini berarti untuk dapat membuktikan kesalahan terdakwa paling sedikit harus didukung oleh "dua orang saksi" dan atau kalau saksi yang ada hanya terdiri dari seorang saja maka kesaksian tunggal itu harus "dicukupi" atau "ditambah" dengan salah satu alat bukti yang lain. Lihat Putusan Mahkamah Agng dalam tingkat kasasi dalam Putusan Tanggal 30 Juni 1983 No.11K/Pidana/1982
}

saja. Pasal 183 tidak membenarkan pembuktian kesalahan terdakwa dengan satu alat bukti yang berdiri sendiri. $^{5}$

Pasal $184 \quad$ KUHAP menempatkan keterangan saksi di urutan pertama di atas alat bukti lain berupa keterangan ahli, surat, petunjuk, dan keterangan terdakwa. Sementara Pasal 185 ayat (2) menyatakan : "Keterangan seorang saksi saja tidak cukup untuk membuktikan bahwa terdakwa bersalah terhadap perbuatan yang didakwakan kepadanya". Namun, Pasal 185 ayat (3) juga menegaskan : "Ketentuan sebagaimana dimaksud dalam ayat (2) tidak berlaku apabila disertai dengan alat bukti yang sah lainnya". Hal ini dapat diartikan bahwa keterangan lebih dari 1 (satu) orang saksi saja tanpa disertai alat bukti lainnya, dapat dianggap cukup untuk membuktikan apakah seorang terdakwa bersalah / tidak. Begitu pentingnya kedudukan saksi dalam mengungkap suatu tindak pidana

\footnotetext{
5 M. Yahya Harahap, Pembahasan ermasalahan dan Penerapan KUHAP Pemeriksaan Sidang Pengadilan, Banding, Kasasi, dan Peninjauan Kembali, Edisi kedua, cet.I, Jakarta, Sinar Grafika, 2000, hal.263
} 
dalam Pasal 184 dan Pasal 185 KUHAP.

Menilik pentingnya saksi sebagaimana ditegaskan dalam ketentuan Pasal 184 - Pasal 185 KUHAP sebagaimana yang duraikan tersebut maka sudah sewajarnya saksi atau korban dalam upaya penegakan hukum diberikan perlindungan, sehingga dalam memberikan kesaksiannya di depan pengadilan, saksi merasa aman dan bebas dari ancaman / tekanan baik fisik atau psikis terhadap diri dan keluarganya. Saksi tidak boleh raguragu menjelaskan peristiwa yang sebenanrnya, walaupun mungkin keterangannya itu memberatkan si terdakwa. Maka Pasal 173 KUHAP memberikan kewenangan kepada Majelis Hakim untuk memungkinkn seorang saksi didengar keterangannya tanpa kehadiran terdakwa. Alasannya jelas, mengakomodir kepentingan saksi sehingga ia dapat berbicara dan memberikan keterangannya secara lebih leluasa tanpa rasa takut, khawatir atau pun tertekan.

Walaupun demikian adanya jaminan keamanan dan bebas dari rasa takut bagi saksi saat diperiksa di muka persidangan atas keterangan yang diberikannya. Sejatinya, jaminan keamanan dan bebas dari rasa takut ini menjadi sangat penting agar saksi tidak raguragu menceritakan peristiwa yang sesungguhnya. Tujuan akhirnya adalah bagaimana mewujudkan rasa keadilan bagi masyarakat.

\section{Perlindungan Saksi dan Korban} Dalam Hukum Positif di Indonesia

Peraturan yang menjadi payung hukum bagi penegak hukum mengenai perlindungan saksi dan korban sudah mendapatkan pengaturan dalam hukum positif. Hal tersebut dapat dilihat dalam hukum pidana materiil dan hukum piddana formil. Pengaturan saksi dan korbandalam hukum pidana materiil terlihat dalam Pasal 14 huruf c KUHP, dalam hal hakim menjatuhkan pidana bersyarat, ditentukan adanya syarat umum dan syarat khusus yang harus dipenuhi oleh terpidana selama dalam masa percobaan. Syarat khusus berupa terpidana dalam waktu tertentu, yang lebih pendek daripada masa percobaannya, harus mengganti segala atau sebagian kerugian yang ditimbulkan oleh perbuatannya.

Pasal 18 ayat (1) huruf $b$ UU No.31 Tahun 1999 jo. UU No.20 
Tahun 2001 tentang Udang-Undang Pemberantasan Tindak Pidana Korupsi disingkat UU PTPK terdapat pidana tambahan berupa pembayaran uang pengganti yang jumlahnya sebanyak-banyaknya sama dengan harta benda yang diperoleh dari tindak pidana korupsi. Begitu juga Pasal 21 UU No.31 Tahun 1999 jo. UU No.20 Tahun 2001 yang mengancam dengan pidana penjara atau pidana denda bagi yang mencegah, merintangi atau menggagalkan penyidikan, penuntutan, dan pemeriksaan terhadap saksi dalam tindak pidana koupsi dan Pasal 24 memberikan perlindungan ata identitas pelapor. ${ }^{6}$

Selain itu juga produk perundang-undangan tindak pidana terorisme yaitu Undang-Undang Nomor 15 Tahun 2003 tentang Tindak Pidana Terorisme dalam Pasal 36 sampai dengan Pasal 42 juga memberikan hak kepada korban atau ahli warisnya untuk memperoleh kompensasi, restitusi

\footnotetext{
${ }^{6}$ Nyoman Serikat Putra Jaya, Sistem Peradilan Pidana (Criminal Justice Sistem), Bahan Kuliah

Program Magister Ilmu Hukum Universitas Diponegoro ,Semarang, 2006, hal 55
}

dan rehabilitasi, berkaitan dengan penderitaan yang dialaminya sebagai akibat terjadinya tindak pidaa terorisme. Ketentuan tersebut diatur lebih lanjut dalam Peraturan Pemerintah No.24 Tahun 2003 tentang Tata Cara Perlindungan terhadap Saksi, Penyidik, Penuntut Umum, dan Hakim dalam Perkara Tindak Pidana Terorisme.

Undang-Undang Nomor 15 Tahun 2002 jo. Undang-Undang Nomor 25 Tahun 2003 tentang Tindak Pidana Pencucian Uang memberikan perlindungan kepada pelapor dan saksi yaitu dengan mewajibkan kepada PPATK, penyidik, penuntut umum atau hakim untuk merahasiakan identitas pelapor. Saksi, penuntut umum, hakim dan orang lain yang bersangkutan dengan tindak pidana pencucian uang yang sedang diperiksa di sidang pengadilan dilarang menyebut nama dan alamat pelapor, atau hal-hal lain yang memungkinkan dapat terungkapnya identitas pelapor. Larangan tersebut pada setiap persidangan diingatkan oleh hakim kepada saksi, penuntut umum atau orang lain yang terkait dengan pemeriksaan tindak pidana pencucian uang. Setiap orang yang 
memberikan kesaksian dalam pemeriksaan tindak pidana pencucian uang, negara wajib memberikan perlindungan khusus dari kemungkinan ancaman yang membahayakan diri, jiwa, dan/atau hartanya, termasuk keluarganya. Pelapor dan/atau saksi tidak dapat dituntut baik secara perdata maupun pidana atas laporan dan/atau kesaksian yang diberikan oleh yang bersangkutan. Di sini nampak bahwa Undang-Undang Nomor 15 Tahun 2002 jo. Undang_undang Nomor 25 Tahun 2003 memberikan dasar hukum, yang menentukan perbuatan pelapor dan/atau saksi yang melaporkan atau memberikan kesaksian tentang adanya tindak pidana pencucian uang bukan merupakan perbuatan melawan hukum, sehingga terlindungi dari adanya tuntutan perdata maupun tuntutan pidana.

Undang-Undang Pengadilan HAM No.26 Tahun 2000 secara teoritis juga mengakui pentingnya aspek perlindungan saksi dan korban dalam proses pengadilan kasus-kasus pelanggaran HAM berat. Pasal 34 dari undang-undang

\footnotetext{
${ }^{7}$ Ibid, hal.56
}

ini menyatakan bahwa aparat penegak hukum dan aparat keamanan diharuskan menyediakan perlindungan bagi saksi dan korban. Dalam hal tersebut pemerintah mengeluarkan Peraturan Pemerintah No.2 Tahun 2002 tentang Tata Cara Perlindungan terhadap Korban dan Saksi dalam Pelanggaran Hak Asasi Manusia yang Berat.

Undang-Undang No.23 Tahun 2004 tentang Penghapusan Kekerasan dalam Rumah Tangga juga memberikan jaminan perlindungan terhadap korban yang diatur dalam Pasal 10 yang mana korban jaminan perawatan kesehatan dari tenaga kesehatan diatur dalam Pasal 21 maupun tenaga sosial yang diatur dalam Pasal 22 UU No.23 Tahun 2004. Selain itu juga dalam UndangUndang No.8 Tahun 1981 terdapat beberapa pasal yang mengatur masalah ganti kerugian yaitu Pasal 77 huruf $b$ tentang ganti rugi dan/atau rehabilitasi, Pasal 95 ayat (1) memberikan jaminan kepada seseorang yang ditangkap, ditahan, dituntut dan diadili atau dikenakan tindakan lain tanpa alasan, dan Pasal 98 ayat (1) jika suatu perbuatan 
yang menjadi dasar dakwaan di dalam suatu pemeriksaan perkara pidana oleh pengadilan negeri menimbulkan kerugian bagi orang lain, maka hakim ketua sidang atas permintaan orang lain dapat menetapkan untuk menggabungkan perkara gugatan ganti kerugian pada perkara pidana.

Undang-Undang No.13 Tahun 2006 tentang Perlindungan Saksi dan Korban selanjutnya disingkat UU PSK. Undang-Undang ini sangat diperlukan untuk mengungkap kasus-kasus besar yang menarik perhatian publik, seperti kasus pelanggaran HAM Berat, terorisme, narkotika/psikotropika, illegal logging, dan tindak ppidana lain yang dianggap menarik perhatian publik. Dengan adanya UU PSK maka perlindungan terhadap saksi dan korban tidak lagi didasarkan pada karitas (charity), atau budi bak aparat penegak hukum dan pemerintahan terkait melainkan sebuah hak (riight) yang dijamin hukum. Apabila sudah menjadi hak yag dijamin hukum, pemenuhannya adalah sebuah keharusan (impperatif). Dengan demikian saksi dan korban memiliki hak hukum yang tidak berdasarkan karitas yang kadang bisa diperoleh, kadang tidak, dan sifatnya sangat relatif-subjektif tetapi hak dan perlindungan saksi dan korban sudah dijamin oeh hukum dengan berasaskan pada penghargaan atas harkat dan martabat manusia, rasa aman, keadilan, tidak diskriminatif dan kepastian hukum yang diatur dalam Pasal 3 UU No.13 Tahun 2006.

Selain itu juga seoorang saksi dan korban berhak : a. memperoleh perlindungan atas keamanan pribadi, keluarga, dan harta bendanya, serta bebas ancaman yang berkenaan dengan kesaksian yang akan, sedang, atau telah diberikannya; b. ikut serta dalam proses memilih dan menentukan bentuk perlindungan dan dukungan keamanan; c. memberikan keterangan tanpa tekanan; d. mendapat penterjemah; e. bebas dari pertanyaan yang menjerat; f. mendapatkan informasi mengenai perkembangan kasus; g. mendapatkan informasi mengenai putusan pengadilan; h. mengetahui dalam hal terpidana dibebaskan; i. mendapat identitas baru; $\mathrm{j}$. mendapatkan tempat kediaman baru; k. memperoleh penggantian biaya transportasi sesuai dengan kebuthan; 1. mendapat nasihat hukum; 
dan/atau; m. memperoleh bantuan biaya hidup sementara sampai batas waktu perlindungan berakhir, yang diatur dalam Pasal 5 UU No.13 Tahun 2006.

\section{Peranan POLRI Dalam Memberikan}

\section{Perlindungan Saksi}

\section{Undang-Undang Nomor 8}

Tahun 1981 tentang Kitab UndangUndang Hukum Acara Pidana yang sellanjutnya disingkat KUHAP saat ini tidak lagi mencukupi kebutuhan untuk menghadirkan sistem peradilan pidana yang modern karena pengaturannya yang tidak mampu memenuhi kebutuhan perkembangan hukum pidana, diantaranya dalam merespon tuntutan proses beracara yang semakin kompleks karena munculnya delik-delik baru dan sistem pembuktian perkara pidana yang berkembang. Salah satu perkembangan dalam hukum pidana adalah tuntutan atas prosedur pidana yang lebih adil bagi para pihak yang terlibat dalam proses peradilan pidana di antaranya para saksi dan korban, dalam hal ini KUHAP masih menitikberatkan pada kepentingan para tersangka, terdakwa dan terpidana semata.
Selain itu, Indonesia juga telah meratifikasi berbagai instrumen hak asasi manusia (HAM) internasional maupun yang terkait dengan tindak pidana internasional, yang mewajibkan Indonesia untuk menyesuaikan instrumen Internasional tersebut dengan berbagai peraturan di tingkat Nasional.

Seiring dengan perkembangan hukum pidana serta untuk menjawab kebutuhan terkait kepentingan saksi dan korban adalah munculnya UndangUndang No. 13 Tahun 2006 tentang Perlindungan Saksi dan Korban yang selanjutnya disebut sebagai UU PSK, sebagai respon atas pentingnya perlindungan saksi dan korban yang selama ini belum cukup diakomodasi dalam berbagai peraturan. UU PSK ini mengatur tentang hak-hak substantif dari saksi dan korban, hak-hak prosedural saksi dan korban, perlindungan terhadap saksi dan korban termasuk mekanisme dan prosedurnya dan juga mengatur mengenai Tugas Pokok dan Fungsi Lembaga Perlindungan Saksi dan Korban ( LPSK ). 
Undang-Undang No.13 Tahun 2006 tentang Perlindungan Saksi dan Korban sudah diundangkan pada tanggal 11 Agustus 2006 namun belum mampu menjawab persoalan masyarakat karena belum terbentuknya komponen hukum lainnya kaitannya dengan perlindungan saksi. Maka peraturan perundang-undangan tentang perlindungan saksi menjadi suatu hal yang sulit untuk dioperasionalisasikan. Namun walaupun demikian aparat penegak hukum sudah dapat memberikan perlindungan kepada para saksi yang memberikan laporan dan kesaksian terhadap adanya dugaan suatu tindak pidana. Menurut Undang-Undang No.13 Tahun 2006 tentang Perlindungan Saksi dan Korban, bentuk perlindungan saksi adalah sebagai berikut : 1 . Perlindungan atas keamanan pribadi, keluarga dan harta bendanya serta bebas dari ancaman yang berkaitan dengan kesaksian yang akan, sedang atau telah diberikan; 2. Ikut serta dalam proses memilih dan menentukan bentuk perlindungan serta dukungan keamanan; 3. Memberikan keterangan tanpa tekanan; 4.
Mendapat penerjemah; 5. Bebas dari pertanyaan yang menjerat; 6 . Mendapatkan informasi mengenai perkembangan kasusnya; 7. Mendapatkan informasi mengenai putusan pengadillan; 8. Diberitahu ketika terpidana dibebaskan; 9. Mendapatkan identitas baru; 10 . Mendapatkan tempat kediaman baru; 11. Penggantian biaya transportasi; 12. Mendapatkan penasihat hukum; 13. Memperoleh bantuan biaya hidup sementara sampai batas waktu perlindungan berakhir.

Sasaran perlindungan yang diberikan Undang-Undang No.13 Tahun 2006, terhadap saksi dan korban diatur dalam Pasal 5 bahwa hak yang diberikan kepada saksi dan/atau korban tindak pidana dalam kasus-kasus tertentu sesuai dengan keputusan Lembaga Perlindungan Saksi dan Korban. Pasal 36 ayat (1) Undang-Undang No.13 Tahun 2006, memberikan mandat kepada Lembaga Perlindungan Saksi dan Korban untuk bekerjasama dengan instansi berwenang lainnya yang terkait, akan tetapi instansi seperti itu hanya diwajibkan melaksanakan keputusan Lembaga Perlindungan Saksi dan 
Korban, sesuai dengan kewenangannya. Instansi dimaksud adalah kepolisian, angkatan bersenjata, departemen tertentu Kemendagri dan Kemenkumham.

UU Kepolisian sampai saat ini tidak mengatur secara tertulis tentang perlindungan saksi dan korban pada proses penyidikan, namun POLRI sebagai penyidik wajib memberikan perlindungan hukum terhadap saksi dan korban kasus KDRT dalam proses penyidikan, ketentuan UU PSK tidak secara eksplisit mengatur hal tersebut, maka UU PSK yang dibuat pada tahun 2006 menjadi dasar hukum bagi Lembaga Saksi dan Korban (LPSK), Undang-Undang dan lembaga ini bertugas untuk memberikan perlindungan hukum dan pemenuhan hak saksi dan korban korban, namun hingga saat ini eksistensi lembaga ini juga masih kurang, hal tersebut tersebut terjadi karena kekurangtahuan masyarakat terhadap lembaga ini, sehingga perlindungan oleh Undang-Undang dan lembaga ini masih belum banyak dirasakan oleh masyarakat khususnya saksi dan korban.
Pemberian perlindungan terhadap saksi dan korban oleh pihak kepolisian pada proses penyidikan dilakukan dengan berlandaskan pada Pasal 13 sampai 15 UU Kepolisian. Polisi sebagai salah satu aktor dalam penegak hukum sesuai dengan amanat Undang-Undang No.2 Tahun 2002 tentang Kepolisian Negara Republik Indonesia khususnya Pasal 2 yang menegaskan fungsi kepolisian adalah salah satu fungsi pemerintahan negara di bidang pemeliharaan keamanan dan ketertiban masyarakat, penegakan hukum, perlindungan, pengayoman, dan pelayanan kepada masyarakat. Berdasarkan pada hal tersebut, POLRI telah melakukan berbagai terobosan yang berkaitan dengan perlindungan saksi dan korban walaupun kendala yang dihadapi cukup banyak.

$\begin{array}{clr}\text { Salah } & \text { satunya } & \text { dengan } \\ \text { membentuk } & \text { Ruang } & \text { Pelayanan }\end{array}$
Khusus di hampir setiap Kepolisian Resor (Polres), atau menjalin kerjasama dengan pihak rumah sakit untuk menangani secara khusus untuk kasus-kasus Kekerasan dalam Rumah Tangga (KDRT). Namun kendala yang dihadapi yaitu 
kurangnya fasilitas pendukung seperti misalnya untuk memenuhi standar minimal suatu ruang pelayanan khusus, padahal ruang khusus tersebut harus memenuhi syarat sebagai berikut :

1. Ruang pelayanan khusus ini letaknya harus terpisah dari ruang pemeriksan yang biasa dipergunakan untuk pemeriksaan tindaka pidana pada umumnya, sekalipun letaknya masih dalam kompleks kantor kepolisian setempat.

2. Ruangan pelayanan khusus harus terasa nyaman dan familiar, tidak seperti ruangan pemeriksaan untuk tindak pidana pada umunya sehingga pada saat korban diperiksa atau dimintai keterangan oleh petugastidak seperti sedang diperiksa di kantor polisi melainkan seperti di rumahnya sendiri.

3. Ruangan pelayanan khusu harus memiliki ruangan relaksasi yang daat dipergunakan oleh korban untuk beristirahat guna memulihkan kondisi fisisk dan mentalnya sehingga pada tahap berikutnya korban siap untuk dimintai keterangan berkaitan dengan kekersan yang menimpa diirinya. ${ }^{8}$

Keterbatasan sumber daya manusia baik secara kuantitas maupun kualitas turut mempengaruhi kualitas pemberian perlindungan hukum terhadap korban tindak pidana. Sebagai contoh di lingkungan institusi kepolisian, terdapat kesenjangan yang sangat lebar antara kepolisian dengan masyarakat, berdampak pula pada kualitas pelayanan yang diberikan oleh aparat kepolisian kepada korban, apalagi jumlah personil ini dikaitkan dengan juamlah (kuantitas) personil polisi wanita.

Masalah kurangnya personil wanita dinyatakan oleh Satjipto Rahardjo, dengan mengutip pernyataan dari Mabes POLRI : kekuatan Polwan apabila dibandingkan dengan kebutuhan tugas Kepolisian Republik

${ }^{8}$ Dikdik M Arief Manssur dan Elisatris Gultom, Urgensi Pelindungan Korban Kejahatan (Antara Norma dan Realita), Jakarta, Rajawali Pess, Hal. 177-178 
Indonesia, baik di bidang operasional maupun pengembangan relatif masih diirasakan kurang, khususnya dalam rangka penugasanpenugasan yang memerlukan pendekatan secara kejiwaan/sosio psikologis. ${ }^{9}$

Disamping jumlah personil yang masih kurang, dari segi kualitas (keahlian) dirasakan masih memprihatinkan, hal ini dapat diperhatikan pada kualitas aparat polisi wanita yang ditugaskan pada unit Ruang Pelayanan Khusus (RPK). Dalam Undang-Undang No.13 Tahun 2006, khususnya Pasal 14 disebutkan bahwa anggota Lembaga Perlindungan Saksi dan Korban (LPSK) terdiri dari tujuh orang yang berasal dari unsur profesional yang mempunyai penglaman di bidang pemajuan, ppemenuhan, perlindungan, penegakan hukum dan hak asasi manusia, kepolisian, kejaksan, Departemen Hukum dan HAM, akdemisi, advokat atau lembaga swdaya masyarakat. Sangat jarang anggota polisi wanita yang memiliki kualifikasi sebagai dokter atau

\footnotetext{
${ }^{9}$ Satjipto Rahardjo, Polisi Siipil Dalam
} Perubahan Sosial di Indonesia, Jakarta, Penerbit Buku Kompas, 2002, hal. 109 psikiater / psikolog yang ditempatkan pada unit ini.

Oleh karena itu, salah satu upaya yang ditempuh untuk mengatasi kendala ini adalah dengan mengirimkan aggota polisi wanita untuk ikut terlibat dalam berbagai pelatihan atau ketrampilan berkaitan dengan masalah-masalah keluarga / rumah tangga, seperti pelatihan tentang pemberdayaan perempuan, psikolog perkembangan anak, kekerasan dalam rumah tangga, dan sebagainya.

Tentu saja tidak mudah bagi aparat hukum, baik di pusat maupun daerah, untuk serta merta mengubah kultur hukum mereka dalam berinteraksi dengan saksi dan korban. Termasuk di dalamnya merealisasi hak-hak yang dimiliki korban. Kultur hukum dari aparat yang berlaku selama inlah menempatkan saksi hanya sebagai pelengkap penderita dalam pelaksanaan sistem peradilan pidana. Setelah saksi dan korban dimintai keterangan di depan persidangan, usai pula peran mereka dalam pelaksanaan sistem peradilan itu. Oleh karena itu agar perlindungan saksi menjadi 
maksimal diperlukan kesadaran hukum masyarakat.

\section{Kesimpulan}

Saksi mempunyai posisi sentral dalam proses perkara pidana karena saksi sangat menentukan kelancaran proses pembuktian dala upaya mencari kebenaran materiel. Saksi juga bukan tidak mungkin adalah sekaligus korban dari adanya suatu tindak pidana. Oleh karena itu mekanisme perlindungan saksi dan korban sangat diperlukan guna mewujudkan keadilan bagi tersangka, korban dan masyarakat.

Jaminan perlindungan saksi dan korban sudah diatur di berbagai peraturan perundang-undangan maupun Undang-Undang No.13 Tahun 2006. Adanya peraturan tersebut dapat dijadikan landasan yuridis bagi aparat penegak hukum khususnya POLRI untuk memberikan perlindungan yang maksimal terhadap saksi dan korban. Namun demikian usaha keppolisian harus diakui masih mempunyai kendala seperti belum adanya peraturan pelaksana, infrastruktur pendukung dan kualitas sumber daya manusia. 


\section{DAFTAR PUSTAKA}

Dikdik M Arief Mansur dan Elisatris Gutom, Urgensi Perlindungan Korban Kejahatan (Antara Norma dan Realita), Jakarta, Rajawali Press, 2007

Farouk Muhammad, Menuju Refoormasi POLRI, cetakan I, Jakarta, PTIK Press bekerjasama dengan CV Restu Agung, 2003

M. Yahya Harahap, Pembahasan Permasalahan dan Penerapan KUHAP Pemeriksaan Sidang Pengadilan, Banding, Kasasi, dan Peninjauan Kembali, Edisi kedua, cet. I, Jakarta, Sinar Grafika, 2000

Muhammad Taufik Makarao, Hukum Acara Pidana Dalam Teori dan Praktek, Jakarta, Ghalia Indonesia, 2002

Muladi, Hak Asasi Manusia, Politik dan Sistem Peradilan Pidana, Semarang, Badan Penerbit Universitas Diponegoro, 2002

Nyoman Serikat Putra Jaya, Siistem Peradilan Pidana (Criminal Justice Sistem), Bahan Kuliah Program Magister Ilmu Hukum Universitas Diponegoro, Semarang, 2006

Satjjipto Rahardjo, Polisi Sipil Dalam Perubahan Sosial di Indonesia, Jakarta, Penerbit Buku Kompas, 2002

Soerjono Soekant, Faktor-Faktor Yang Mempengaruhi Penegakan Hukum, Jakarta, PT Raja Grafindo, 1993

Undang-Undang No. 13 Tahun 2006 Tentang Perlindungan Saksi Dan Korban 